\title{
VIGS IN AFRIKA, MET SPESIALE VERWYSING NA SUID-AFRIKA
}

\author{
A.T. Viljoen \\ Departement Anatomie \\ Potchefstroomse Universiteit vir CHO \\ POTCHEFSTROOM
}

\begin{abstract}
It is generally accepted that Africa is the continent that is most seriously affected by the AIDS epidemic. As a result of under-reporting the actual incidence of AIDS may be more than ten times higher than indicated by the official figures. The majority of females of child-bearing age can be infected within the next 46 years. Infant mortality is expected to increase dramatically. Up to 50\% of babies bom to HIV-infected mothers are also infected. Most of these babies will develop an AIDS-related illness and die at a very young age. Twelve factors have been identified which place the black population of South-Africa among the highest risk groups in the world. No vaccine or cure is available at this stage. Education of the general population, with the aim to bring about a change in scxual practices, is the only way to prevent a demographic catastrophe in this country.
\end{abstract}

\section{INLEIDING}

VIGS is vir die eerste keer in 1981 in die VSA gediagnoseer. Sedertdien het dit na alle kontinente, en waarskynlik na alle lande van die wêreld versprei. VIGS (verworwe immuniteitsgebreksindroom) word veroorsaak deur 'n virus, algemeen bekend as HIV (human immunodeficiency virus). Daar is reeds twee duidelike onderskeibare stamme van die virus geïdentifiseer, naamlik HIV-1 en HIV-2. Laasgenoemde is hoofsaaklik beperk tot die lande van Wes-Afrika. HIV-2 is waarskynlik nie so virulent (aggressief) soos HIV-1 nie, word nie so maklik oorgedra nie en kom reeds vir 'n baie lang tyd in die bevolking voor. HIV-1 is egter vinnig besig om HIV-2 te vervang as vernaamste oorsaak van VIGS in hierdie lande. (In verdere besprekings sal geen onderskeid tussen HIV-1 en HIV-2 gemaak word nie.)

VIGS is hoofsaaklik 'n seksueel-oordraagbare siekte. Die gebruik van HIV-besmette bloed by bloedoortappings was vroeër ook 'n belangrike bron van besmetting, maar sedert bloed vir die teenwoordigheid van anti-liggame teen die virus getoets word, het hierdie bron van besmetting grootliks verdwyn. Ongeveer $9 \cdot 10 \%$ van alle VIGS. gevalle in Suid-Afrika het die infeksie langs hierdie weg opgedoen. In sommige lande is die gebruik van besmette spuitnaalde deur binne-aarse dwelmgebruikers ook 'n belangrike oorsaak van infeksie. 


\section{VIGS IN AFRIKA}

Dit word vandag algemeen aanvaar dat Afrika met 'n bevolking van ongeveer 500 miljoen die kontinent is wat die hardste deur die VIGS-epidemie getref word (Mann, 1988:60-69). Tot aan die einde van Januarie 1990 is 'n kumulatiewe totaal van 40304 gevalle by die Wêreld Gesondheidsorganisasie (WGO) aangemeld (World Health Organization 1990:1-8). Die werklike getal kan egter tot 10 maal hoër wees as wat amptelik aangetoon word (Kingman, 1988:20). Dit is slegs in Westerse lande met ' $n$ goedontwikkelde gesondheids-, tegnologiese- en kommunikasiestelsel waar syfers enigsins betroubaar is. In die meeste Afrikalande is hierdie stelsels swak ontwikkel of bestaan byna glad nie. Baie lande ontken selfs, waarskynlik om politieke redes, die voorkoms van VIGS binne hulle grense. Slegs 'n klein gedeelte van die lande, onder andere Suid-Afrika, rapporteer gereeld aan die WGO. Waar syfers wel beskikbaar is, is dit in die meeste gevalle verouderd. Die werklike beeld verskil dus grootliks van dit wat amptelik bekend is. Die lvoorkus aan die Weskus van Afrika kan in hierdie opsig as voorbeeld dien.

Die Ivoorkus het 'n bevolking van tussen 10 en 11 miljoen mense waarvan ongeveer 1.95 miljoen in die hoofstad Abidjan woon. Die eerste gevalle van VIGS is in 1985 hier aangemeld (De Cock et al., 1989:408-411). Die gemiddelde voorkoms van HIV was op daardie stadium ongeveer $1.6 \%$ waarvan $3.2 \%$ in die stedelike gebiede en $1.1 \%$ op die platteland voorgekom het (Quattara et al., 1989:94-99). Teen November 1988 was daar volgens De Cock et al. (1989:408-411) reeds 3397 VIGS-pasiënte per jaar in twee van die grootste hospitale in Abidjan alleen behandel. Hierdie outeurs beweer ook verder dat ' $n$ hele aantal mense na hulle gebiede van herkoms op die platteland terugkeer sodra hulle begin siek word. Hierdie pasiënte is dus nie by bogenoemde syfers ingesluit nie. Ongeveer 33\% van alle sterftes in hierdie hospitale kan aan VIGSverwante oorsake toegeskryf word.

Met 'n verdubbelingstyd van 12 maande kan daar dus ongeveer 6800 VIGS-gevalle gedurende 1989 in Abidjan alleen voorgekom het. Konserwatief bereken, kan daar ook dieselfde aantal gevalle in die res van die land voorgekom het - 'n totaal van 13 600. Dit beteken dat meer as 1 uit elke 1000 inwoners van die Ivoorkus reeds aan VIGS ly. As aanvaar word dat vir elke geval van VIGS daar ongeveer 100 ander persone bestaan wat reeds met HIV geïnfekteer is (Roos, 1988:16-19), beteken dit dat ongeveer 1.36 miljoen mense of $10 \%$ van die totale bevolking reeds met die virus besmet is. Daarteenoor rapporteer die WGO slegs 760 gevalle vir 1988 en geen gevalle vir 1989 nie (tabel 1). 
TABEL 1 DIE GERAPPORTEERDE EN VERWAGTE AANTAL VIGS GEVALLE VIR 'N AANTAL AFRIKASTATE

\begin{tabular}{|c|c|c|c|c|c|c|}
\hline \multirow[t]{2}{*}{ Land } & \multirow{2}{*}{$\begin{array}{l}\text { Bevolking } \\
\text { miljoene }\end{array}$} & \multicolumn{3}{|c|}{ Vigs volgens WGO } & \multirow{2}{*}{$\begin{array}{l}\text { Verwagle } \\
\text { Vigs gevalle }\end{array}$} & \multirow{2}{*}{$\begin{array}{l}\text { Laasle } \\
\text { rapport }\end{array}$} \\
\hline & & 1988 & 1989 & Tolaal" & & \\
\hline- & & & & & -1 & \\
\hline Angola & 90 & 63 & 0 & 104 & $90(\kappa)$ & $31-12-88$ \\
\hline Burundi & 47 & 1055 & 380 & 2355 & $47(m)$ & $3006-89$ \\
\hline Chad & 70 & 7 & 10 & 21 & 7000 & $17-11-89$ \\
\hline Ivoorkus & 100 & 760 & 0 & 1010 & $100 \times 10$ & $23-10-89$ \\
\hline Etiopie & 62 & 62 & 178 & 259 & 6200 & 06.11 .89 \\
\hline Ghana & 126 & 266 & 750 & 1077 & 12600 & $31-10-89$ \\
\hline Gulnle & 58 & 29 & $4 !$ & 82 & $58(x)$ & 10-10-89 \\
\hline Kenia & 204 & 2817 & 1690 & 60104 & $204(x)$ & $30-06-89$ \\
\hline Malawi & 7.1 & 1582 & 0 & 2586 & 71100 & $30-106-88$ \\
\hline Mali & 7.6 & 0 & 0 & 29 & 76100 & $14-01-88$ \\
\hline Mosamblek & 115 & 23 & 29 & 56 & 115100 & $20-12-89$ \\
\hline Niger & 86 & 26 & 13 & 56 & 86100 & $31-03-89$ \\
\hline Nigerie & 970 & 3 & 22 & 35 & 97000 & $02-08-89$ \\
\hline Rwanda & BO & 267 & 539 & 1806 & 6010 & $31-(18-89$ \\
\hline Senegal & 63 & 115 & 88 & 269 & 63110 & $11-11-89$ \\
\hline Tanzaniè & 227 & 2550 & 1469 & 5627 & 22700 & $31-12-89$ \\
\hline Uganda & 15.4 & 4072 & 603 & 7375 & 15400 & 15-04-89 \\
\hline Zalr & $301)$ & 2788 & 0 & 4636 & $300 \times 10$ & $31-12-88$ \\
\hline Zambiß: & 70 & 1057 & 727 & 2417 & 7010 & $30-10899$ \\
\hline Zimbabwe & 84 & 202 & 827 & 1148 & 84110 & $30-09-89$ \\
\hline Totaal & 3033 & 14195 & $485 R$ & 36598 & 303310 & \\
\hline
\end{tabular}

- Die totale aantal gevalle sedert 9979

Bron: World Health Organizalion 1989 
Indien 'n soortgelyke situasie in die ander lande van swart Afrika bestaan, kom 'n on. stellende beeld na vore. Die totale bevolking van hierdie lande is ongeveer 330 miljuen. Dit sou dan beteken dat ongeveer 230000 mense reeds tot by volwaardige VIGS jevorder het, en dat ' $n$ verdere 23 miljoen met HIV geïnfekteer is. Die jongste gegewens uit Uganda, 'n staat in Oos-Afrika, bevestig hierdie vermoede. Uit twee gemeenskappe, met 'n totaal van ongeveer 70000 inwoners, in die omgewing van die hoofstad Kampala, was $10.8 \%$ teen Augustus 1987 met HIV geïnfekteer. Hierdie twee gebiede word as semi-stedelik beskou (Konde-Lule et al., 1989:513-518). Vandag, ongeveer twee en 'n half jaar later, kan verwag word dat hierdie syfer veel hoër sal wees.

Die gerapporteerde en verwagte aantal gevalle van VIGS vir 'n aantal Afrikastate word in tabel 1 weergegee. Let daarop dat nie al die Afrikastate ingesluit is nie. Die situasie in die Arabiese lande, byvoorbeeld Libië en Egipte, kan op hierdie stadium nie bepaal word nie.

As verder aanvaar word dat ongeveer $50 \%$ van die bevolking onder die ouderdom van 20 jaar is, en dat die aantal gevalle van VIGS en HIV-infeksie elke jaar verdubbel beteken dit dat die hele volwasse bevolking van ongeveer 165 miljoen binne drie tot vier jaar geïnfekteer sal wees. Die huidige aanduidings is dat $50 \%$ van alle geïnfekteerde persone (ook genoem HIV-positief) binne vyf tot ses jaar een of ander VIGSverwante siektetoestand sal ontwikkel (Giesecke et al., 1988:99-102; Costagliola et al., 1989:768-769). Daar word ook verwag dat die oorgrote meerderheid HIV-positiewe persone uiteindelik VIGS sal ontwikkel en sterf, ongeag die wyse waarop die infeksie opgedoen is (Lui et al., 1988:1333-1338; Reeves, 1989:147-151).

VIGS is egter nie beperk tot die ouderdomsgroep bo 20 jaar nie. Tot $50 \%$ van alle babas wie se moeders HIV-positief is, sal by geboorte ook positief wees. Die meeste van hierdie babas sal binne een jaar VIGS-verwante siektetoestande ontwikkel en op vroeë ouderdom sterf (Johnson et al., 1989:1147-1153). Namate HIV dus onder die vroulike bevolking toeneem, sal daar 'n ooreenstemmende toename in die aantal kindersterftes wees. Op 'n vasteland waar kindersterftes reeds baie hoog is, kan dit 'n katastrofale uitwerking op die bevolking hè.

Baie babas wat nie met HIV geinfekteer is nie sal op ' $n$ vroeë ouderdom wees gelaat word as bulle ouers sterf. Talle sal dan as gevolg van gebrek aan ouerlike sorg ook sterf. Dit moet oorweeg word of hierdie sterftes nie ook as VIGS-verwante sterftes beskou moet word nie.

Die toename van HIV-infeksie onder die ouderdomsgroep 15-20 jaar dui daarop dat kinders reeds op 'n vroeë ouderdom seksueel aktief is. Hierdie kinders wat van 'n 
geen-risikogroep na 'n hoër-risikogroep beweeg, word die rekrute genoem. Namate die persone in die hoër ouderdomsgroepe VIGS opdoen en sterf, sal die rekrute daarvoor verantwoordelik wees dat die gemiddelde ouderdom van VIGS-gevalle ook sal daal.

In Afrika is VIGS hoofsaaklik 'n seksueel-oordraagbare siekte. Daar is geen bewyse dat dit deur insekvektore soos muskiete, weeluise of ander insekte oorgedra word nie Toevallige kontak tussen persone binne gesins- of werksverband kan dit ook nie oordra nie (Lifson, 1988:1353-1356). Daar sal dus 'n gedeelte van die bevolking wees wie se lewenswyse sodanig is dat hulle nie die siekte sal opdoen nie. Hoe groot hierdie gedeelte van die bevolking is, is onbekend. Uiteindelike sal dit net hulle wees wat oorbly en die bevolking weer sal opbou. Omdat hulle sedelike en morele waardes anders is as dié van die huidige bevolking, kan verwag word dat die waardes van postVIGS Afrika ook aansienlik anders daar sal uitsien as die huidige.

\section{VIGS IN SUID-AFRIKA}

In Suid-Afrika word sowel die Westerse as die Afrikapatroon van oordrag aangetref. In die blanke bevolking is die siekte tot nog toe hoofsaaklik beperk tot homo-en biseksuele mans, asook ontvangers van bloed en bloedprodukte. In die swart gemeenskap vind oordrag hoofsaaklik in die heteroseksuele gedeelte van die bevolking plaas, asook van moeder na kind. Die voorkoms van VIGS in Suid-Afrika word in tabel 2 aangetoon.

Wat veral opmerklik is, is dat meer swart vroue as mans die siekte opgedoen het en dat 'n relatiewe groot aantal swart kinders dit van hulle moeders gekry het. Dit bevestig 'n vroeëre argument dat die aantal kindersterftes gaan toeneem.

Hoewel die voorkoms van VIGS by blanke vroue nog baie laag is kan verwag word dat dit een of ander tyd ook'n toename sal toon soos in die meeste Westerse lande (Holmes \& Kreiss, 1988:602-610). Aangesien die heteroseksuele bevolking baie groter is as die homo- en biseksuele bevolking kan verwag word dat eersgenoemde later die meerderheid van gevalle gaan uitmaak.

Die beskikbare syfers vir kleurlinge en Asiërs is tans nog te laag om tot 'n betroubare gevolgtrekking te hom. Dit kan egter verwag word dat vir die kleurlinge 'n Afrikapatroon, en vir die Asiërs 'n Westerse patroon sal ontwikkel. Die komende jaar of twee sal hieroor meer duidelikheid bring. 
TABEL 2 DIE VOORKOMS VAN VIGS ONDER DIE VERSKILLENDE BEVOLKINGSGROEPE IN SUID-AFRIKA SOOS OP 12 TEBRUARIE 11990

\begin{tabular}{|c|c|c|c|c|c|c|c|c|c|}
\hline \multirow[t]{2}{*}{ Tipe Ourdrag } & \multicolumn{2}{|c|}{ swar1 } & \multicolumn{2}{|c|}{ Blank } & \multicolumn{2}{|c|}{ Kleurling } & \multicolumn{2}{|c|}{ Asier } & \multirow{2}{*}{ Totaal } \\
\hline & M & $\checkmark$ & $M$ & $v$ & M & $v$ & $M$ & $v$ & \\
\hline Homo-en biseksueel & 2 & - & 202 & - & 8 & 1 & 3 & & 216 \\
\hline Heteroseksueel & 27 & 35 & 6 & 2 & 1 & 1 & & - & 72 \\
\hline \multicolumn{10}{|l|}{ Blued en bloedprodukle } \\
\hline Volwasse & 1 & - & 1.3 & 1 & 1 & - & - & & 16 \\
\hline Kinders & 3 & - & & & 1 & - & - & 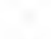 & 4 \\
\hline Onbekend & 1 & - & 4 & 2 & - & - & - & $=$ & 7 \\
\hline Dwelmverslaal & - & - & 1 & $\cdot$ & - & - & - & & 1 \\
\hline \multirow[t]{2}{*}{ Moeder na kind } & 6 & 4 & - & - & - & - & . & 1 & 10 \\
\hline & 40 & 39 & 226 & 5 & 11 & 2 & 3 & . & 326 \\
\hline
\end{tabular}

Bron: Suid A.lrika (Republiek) 1990

Hoewel slegs 79 swartmense teen 12 Februarie 1990 in Suid-Afrika die siekte opgedoen het (Suid-Afrika, 1990:1-3), bestaan daar 'n aantal risikofaktore wat hierdie bevolkingsgroep moontlik onder die groepe met die hoogste risiko ter wêreld plaas. Die volgende faktore kan as die belangrikste beskou word. 


\section{FAKTORE WAT DIE VERSPREIDING VAN VIGS ONDER DIE SWART BEVOIKING BEINVLOED}

\section{1 'n Tipiese Afrikapatroon}

Indien VIGS tot 'n bepaalde groep, byvoorbeeld homoseksuele mans of dwelmverslaafdes, beperk was, sou die invloed daarvan op bevolkingsgetalle beperk wees. Wanneer dit egter die heteroseksuele bevolking binnedring, is almal wat seksueel aktief is potensieel vatbaar. Die vernaamste faktor wat dan die verspreiding sal bepaal, is die mate van promiskuïteit van die bepaalde bevolking.

Tans word drie verspreidingspatrone in die wêreld geỉdentifiseer. Die Westerse patroon word in lande met 'n Westerse lewenswyse aangetref. Dit sluit die lande van Noord-Amerika, Wes-Europa, Australië, Nieu-Zeeland en die blankes van Suid-Afrika in. Die oorgrote meerderheid VIGS-gevalle kom hier voor by homoseksuele mans, dwelmverslaafdes en ontvangers van bloed of bloedprodukte. Die Afrikapatroon kom in Afrika en sommige lande van Sentraal- en Suid-Amerika voor. Ongeveer ewe veel mans as vroue word geïnfekteer en die vernaamste verspreidingsroete is deur heteroseksuele geslagsomgang, dit wil sê tussen man en vrou. 'n Derde patroon word in die lande van Oos-Europa en Asië aangetref. Hier is die amptelike syfer baie laag en hoofsaaklik beperk tot buitelanders en hulle seksuele kontakte. Daar is egter aanduidings dat ook in hierdie lande 'n Afrikapatroon besig is om te vestig, veral onder die minder gegoede deel van die bevolking (Schneider, 1989:72-90).

In die geval van swartmense in Suid-Afrika word 'n tipiese Afrikapatroon aangetref. Van die 79 gevalle wat tot 12 Februarie 1990 aangeteken is, is 31 mans, 35 vroue en 13 kinders. Die huidige tendens dui daarop dat meer swart vroue as mans geïnfekteer word. Dit hou besondere implikasie in vir die geboortesyfer en kindersterftes soos later aangedui sal word. Alle inligting in ag genome, kan tot $85 \%$ van die totale swart bevolking tussen die ouderdom van 15-65 jaar as 'n hoë risikogroep beskou word. Met 'n huidige totaal van meer as 50000 geïnfekteerde persone, en 'n verdubbelingstyd van een jaar, kan tot 12 miljoen swartmense teen die einde van 1998 met HIV geïnfekteer wees. Alle aanduidings is dat ongeveer $50 \%$ van alle geïnfekteerde persone binne ses jaar die siekte opdoen en binne die daaropvolgende twee jaar sterf. Onlangse studies onr die verloop van die siekte dui ook daarop dat baie na aan $100 \%$ van alle infeksies uiteindelik fataal sal wees (Moss \& Bacchetti, 1989:55-61).

Die ouderdomsgroep 1-15 jaar maak op die oomblik ongeveer $41 \%$ van die swart bevolking uit. Namate hulle die ouderdom van 15 jaar bereik en seksueel aktief begin raak, kan hulle as rekrute tot die epidemie beskou word. Indien hulle die seksuele gedrag van die ouer geslag navolg, sal hulle op vroeë ouderdom reeds met die virus 
geinfekteer word, VIGS opdoen en sterf. Daar kan dus verwag word dat die gemiddelde ouderdom van VIGS-sterftes met verloop van tyd aansienlik gaan daal.

\subsection{Onderrapportering}

Die vermoede bestaan dat 'n aansienlike onderrapportering van VIGS by swartes voorkom. Die hoë voorkoms van siektes soos tering, malaria, gastro-enteritis en ander het waarskynlik 'n hele aantal VIGS-verwante sterftes verbloem. In afgeleë gemeenskappe sterf mense dikwels en word begrawe sonder dat 'n behoorlike diagnose van die oorsaak van die sterfte gemaak is. In al die lande van Suidelike Afrika is daar lank reeds 'n hoë voorkoms van VIGS en dit sal dus vreemd wees as dit nie ook al 'n geruime tyd in Suid-Afrika voorgekom het nie. Die werklike aantal VIGS-gevalle kan dus aansienlik meer wees as die 79 wat aangemeld is.

\subsection{Tradisie}

Poligamie is tradisioneel eie aan die swart volke van Suid-Afrika. 'n Man se rykdom was gemeet aan die aantal beeste en vroue wat hy besit het. Volgens Mokhobo (1988; 34 ) word hierdie tradisie in 'n nuwe vorm voortgesit deur met 'n groot aantal vroue seksuele kontak te hê. Daar is ook 'n Tswanaspreekwoord wat lui: Monna ke phologolo o a eta ('n Man is 'n wildsbok, hy kuier). Verskeie ondersoeke het reeds angetoon dat daar 'n positiewe korrelasie bestaan tussen die aantal seksmaats en die HIV-infeksie (Sandberg \& Awerbuch, 1989:467-477); Bonneux et al., 1989:581-584). Hierdie korrelasie is logies. Hoe meer seksmaats 'n persoon (genoem die indekspersoon) het, hoe groter is die kans dat een daarvan reeds met die virus geinfekteer kan wees. Die aantal ongeïnfekteerde persone aan wie die ir 'ekspersoon weer die virus kan oordra is dan ook soveel groter.

Volgens Mokhobo (1988:34) soek swartmense in enige gebeure altyd 'n verband tussen vorsaak en gevolg. Dit gaan baie moeilik wees om hulle te oortuig dat 'n "oortreding" wat met die een deel van die liggaam, in hierdie geval die geslagsorgane, gepleeg word, "gestraf" word in 'n ander deel van die liggaam, byvoorbeeld die longe, of die spysverteringskanaal (gastro-enteritis) of selfs die brein in die gevalle waar die virus die senuweestelsel aantas.

Dié tradisionele beskouing is 'n belangrike struikelblok in enige program wat deur opvoeding en inligting die siekte probeer bekamp. 


\subsection{Trekarbeid}

Trekarbeiders maak 'n groot deel van die Suid-Afrikaanse arbeidsmag uit. Na raming is daar ongeveer 300000 arbeiders uit buurstate wat wettig binne die landsgrense vertoef, asook 'n onbekende aantal onwettige arbeiders, veral in die gebiede na aan die grense. Die grootste aantal trekarbeiders is egter van binne die landsgrense afkomstig. Die TBVC lande (Transkei, Bophutatswana, Venda en Ciskei), selfregerende nasionale state en plattelandse gebiede is die vernaamste voorsieners van trekarbeiders. Hierdie mense, meestal mans tussen die ouderdom van 20-25 jaar, vind huisvesting in plekke soos enkelkwartiere, dikwels op die terrein van die werkgewer, byvoorbeeld die myne, of andersins in swart stedelike gebiede. Ander bly by familie of kennisse of vind privaat losies. In sommige gebiede, byvoorbeeld die goudvelde van Transvaal en die Vrystaat, maak vroue soms slegs $5 \%$ van dié bevolking uit.

Baie trekarbeiders is getroud en behou hulle bande met hulle gesinne in die gebied van oorsprong. As gevolg van lang tye weg van die huis word seksuele verhoudings dan met girl friends, houvroue of prostitute aangeknoop (Moodie, 1988:228-256). Omdat geen formele bande bestaan nie, is hierdie verhoudings nie baie stabiel nie en word dit na willekeur geskep en verbreek. 'n Aansienlike deel van hierdie arbeiders se salaris word dan op geskenke en betaling vir "dienste" gespandeer en minder geld word na die gesin tuis gestuur. Om te oorleef, knoop hierdie vroue dan ook weer sekondêre verhoudinge aan, dikwels met verskeie mans. Onder hierdie omstandighede kan verwag word dat die virus vinnig sal versprei.

\subsection{Mobiliteit van die bevolking}

Baie van die permanente inwoners van swart stedelike gebiede behou, soos die trekarbeiders, hulle bande met die gebiede waaruit hulle of selfs hulle ouers kom. Gedurende naweke en vakansietye is daar ' $n$ baie groot verkeersvloei tussen swart dorpe en die landelike gebiede. Hierin speel die minibussies, waarvan daar ongeveer 100000 is, 'n baie belangrike rol. Baie van hierdie bussies lê tot ses ritte per naweek oor lang afstande af; drie ritte tussen Vrydagnag en Saterdagoggend om passasiers weg te bring, en drie ritte tussen Sondagmiddag en Maandagoggend om hulle weer te gaan haal. In baie gevalle word baie meer passasiers ingelaai as wat deur die betrokke ordonnansies toegelaat word. Die aantal passasiers wat op hierdie manier vervoer word, kan met gemak een miljoen of meer per naweek bereik.

Groot hoeveelhede vrag word per pad met behulp van vragmotors oor lang afstande vervoer, selfs tot ver buite die grense van Suid-Afrika. Dit gebeur dus dikwels dat een of meer nagte weg van die huis deurgebring moet word. Baie van hierdie vragmotors is

Koers 55(3) 1990:329-343 
VIGS in Afrika, met spesiale veruysing na Suid-Afrika

ook met 'n dubbelkajuit toegerus, waarvan een as slaapkwartier dien. Padverkeer is 'n baie belangrike verspreidingsroete vir VIGS in Afrika (Edelston, 1988:169) en dit kan verwag word dat dit ook hier so sal wees.

Minibussies en swaar vragmotors is dus uiters doeltreffend om HIV-infeksie vinnig en oor groot afstande te versprei.

\subsection{Geboortebeperking}

Suid-Afrika is 'n land wat ryk is aan baie natuurlike hulpbronne soos steenkool, minerale, ensovoorts. Daar bestaan egter toenemende kommer dat die land se hulpbronne nie onbepaald in die behoeftes van 'n groeiende bevolking sal kan voorsien nie. Suid-Afrika is 'n relatief droë land en watervoorsiening is reeds 'n probleem, soos wat hewys word deurdat waterbeperkings dikwels gedurende droë tydperke ingestel moet word. In 'n verslag van die Wetenskapskomitee van die Presidentsraad (Suid-Afrika, 1983 ) word beraan dat Suid-Afrika 'n maksimum bevolking van ongeveer 80 miljoen sal kan onderhou.

Om die snelle toename van bevolkingsgetalle te beperk, is ' $n$ bevolkingsontwikkelingsprogram van stapel gestuur om swartes aan te moedig om gesinsbeplanning toe te pas. Voorbehoedmiddels is vrylik beskikbaar gestel en by klinieke kan vroue gratis 'n inspuiting ontvang wat swangerskap vir tot drie maande kan voorkom.

Met die vrees vir onbeplande swangerskappe grootliks uitgeskakel, het veral jong swart meisies tot die seksueel-aktiewe bevolking toegetree. In 'n onlangse ondersoek is gevind dat byna $30 \%$ vna alle HIV-positiewe bloedskenkers in Natal nog op skool is en byna 100\% van die groep tussen 17 en 19 jaar meisies is (Prior \& Buckle, 1990). Deeltydse prostitusie het ' $n$ vinnige en maklike manier geword om geld te verdien om nodige of luukseartikels te koop, wat met die dikwels karige gesinsinkomste nie beskikbaar was nie. Soos een opgemerk het: "Vrydag word die mans 'gepay' en Maandag het ons die geld."

\subsection{Armoede}

As gevolg van die lae akademiese kwalifikasies van 'n groot gedeelte van die swart bevolking, is die gemiddelde inkomste per gesin baie laag. Baie gesinshoofde werk as onopgeleide arbeiders, dikwels as dagloners wat stukwerk in tuine, konstruksiewerke of ander laag besoldigde tydelike posisies verrig. Sanksies deur die internasionale gemeenskap om Suid-Afrika te dwing om van apartheid af te sien, het grootliks byge- 
dra tot werkloosheid. Daar word bereken dat sanksies en disinvestering 'n direkte verlies van ongeveer R40 biljoen tot gevolg gehad het. Die totale effek hiervan het egter 'n verbruikersbestedingsverlies van ongeveer R 100 biljoen meegebring. Ironies genoeg, is juis die swart bevolking die swaarste getref deur hierdie maatreëls ( $\mathrm{Van}$ Wyk, 1989). Al sou sanksies as gevolg van toegewings van regeringskant onmiddellik opgehef word, sal dit nog 'n geruime tyd duur voordat die ekonomie sodanig sal herstel dat werkloosheid drasties verminder kan word. Armoede sal dus vir die afsienbare tyd nog ' $n$ wesentlike kenmerk van'n groot gedeelte van die swart bevolking wees.

Onder hierdie omstandighede is prostitusie dikwels die enigste oorlewingsmoontlikheid vir talle gesinne (Viljoen, 1989:1280). Hierdie gedwonge prostitute vind gewillige kliënte in die groot aantal mans wat as trekarbeiders in groot getalle naby die stede voorkom. Daar is aanduidings dat hierdie mans toenemend van die dienste van prostitute gebruik maak eerder as om 'n meer vaste verhouding met 'n houvrou of girl friend aan te knoop.

\subsection{Verstedeliking}

Verstedeliking is 'n wêreldwye verskynsel en het in die jongste tyd ook grootliks in Suid-Afrika toegeneem. In baie gevalle kan die bestaande stedelike infrastrukture hierdie toeloop van mense nie hanteer nie met die gevolg dat plakkerskampe oral ontstaan het. Sommige van hierdie kampe, byvoorbeeld die berugte Cross Roads naby Kaapstad, het geweldig vinnig gegroei en haglike toestande het ontstaan. Onder hierdie omstandighede het die meeste erkende en bekende tradisionele sosiale strukture totaal verval en is deur nuwes vervang. Selfs in die meer gevestigde townships heers daar ander omstandighede as dié waaraan nuwe intrekkers gewoond was. Die ideale waarmee die nuwelinge hulle vorige tuistes verlaat het, word meestal ook nie verwesenlik nie en blote oorlewing word van kardinale belang.

Waar die tradisionele toesig van hoofmanne en familie nie meer geld nie, word ook nuwe seksuele vryheid gevind. Hierdie toestande is ideaal vir die oordrag van die VIGS-virus.

\subsection{Politieke faktore}

Suid-Afrika staan midde in grootskaalse politieke veranderinge. Vir die meeste swart leiers word dit waarvoor hulle hulle jare lank beywer het nou verwesenlik. Daar is talle sake soos opvoeding, arbeidsaangeleenthede, behuising en andere wat onmiddellike en dringende aandag verg. Die gevolge van VIGS is nog nie sigbaar 
teenwoordig nie en in 'n gemeenskap wat met talle ander probleme worstel, beklee dit 'n baie lae prioriteit by die meeste swart leiers (Naudé, 1990). Baie swartmense beskou enige poging om hulle seksuele gewoontes te verander met agterdog. Vir hulle is dit net nog 'n poging van die kant van die blankes om die swart bevolking se getalle te verminder om sodoende politieke mag te behou (Mokhobo, 1988:34). Die opmerking dat die akroniem AIDS, staan vir Afrikaner Ideas to Discourage Sex is ook al uit die swart gemeenskap gehoor. Tot tyd en wyl groot getalle swartmense bewus word van die gevaar van VIGS en hierdie boodskap aan hulle eie mense oordra, sal pogings om die verspreiding te bekamp nie met groot sukses beloon word nie.

\subsection{Drankmisbruik}

Drankmisbruik kom op groot skaal voor onder die swart bevolking. Volgens 'n bekende gemeenskapsleier in Ikageng, die swart woonbuurt van Potchefstroom, sal drankmisbruik grootliks daarvoor verantwoordelik wees dat maatreëls om VIGS te bekamp, misluk (hierdie leier verkies om anonniem te bly uit vrees vir intimidasie). Hy beweer dat waar mans saam drink dit net 'n klein tydjie duur voordat die gesprek oor seks gaan. Wanneer hulle dan uitgaan om woorde in dade oor te sit, laat alkohol hulle van alle gevare vergeet. In hierdie toestand is hulle dan ook nie vatbaar vir oortuiging om veilige seks te beoefen deur' 'n kondoom te gebruik nie.

Drankmisbruik is natuurlik ook weer 'n simptoom van 'n groot aantal ander sosio-ekonomiese probleme wat in ag geneem sal word by die beplanning van ' $n$ voorkomingstrategie.

\subsection{Ander seksueel-oordraagbare siektes}

Verskeie navorsers het 'n duidelike verband gevind tussen die voorkoms van seksueeloordraagbare siektes soos sifilis, gonorree, genitale ulseratiewe siektes, kandidiase en andere (European Study Group, 1989; Bonneux, 1988). Die rede hiervoor is waarskynlik omdat hierdie siektes die gesonde epiteel van die betrokke organe beskadig en sodoende aan die virus toegang tot die bloedstroom verleen. Gesonde epiteel van die mond en geslagsorgane is 'n baie doeltreffende versperring teen die virus omdat hierdie selle nie die bepaalde bindingspunte bevat waaraan die virus moet heg om die sel te kan binnedring nie.

Dit is bekend dat ' $n$ baie groot deel van die swart bevolking met een of meer van hierdie geslagsiektes besmet is en dus baie vatbaar vir die virus is (Piot \& Laga, 1989). 


\subsection{Onrus en geweld}

Dit wil voorkom asof daar ' $n$ verband bestaan tussen die voorkoms van onrus en geweld in swart gebiede en die verspreiding van HIV. Dit is op hierdie stadium nie duidelik of dit ' $n$ toevallige of direkte verband het nie. In onrussituasies verval wet en orde, asook sedelike norme. Verkragtings, aanrandings en intimidasie neem geweldig toe en word in die meeste gevalle nie aangemeld nie. Daar kan dus verwag word dat die hoë voorkoms van HIV, byvoorbeeld in Natal, meer as net toevallig is.

\section{TEN SLOTTE}

Dit word allerweë erken dat die wêreld deur menslike optrede op 'n aantal natuurrampe afstuur. Sommige hiervan het sodanige omvang bereik dat dit as eko-katastrofes bestempel kan word. 'n Eko-katastrofe kan gedefiniëer word as 'n natuurramp van wêreldwye omvang wat die hele mensdom sal raak (Pollunin, 1974:177-189). Hieronder kan besoedeling, woestynuitbreiding, metaboliese defekte en kernoorloë ingesluit word. Die grondslag van al hierdie potensiële gevare is die eksponensiële toe name in menslike getalle wat deur Cloudsley-Thompson (1977:66-68) as "the ultimate ecodisaster" beskryf is.

Min kon hierdie twee outeurs weet dat, terwyl hulle besig was om aan die probleem van oorbevolking te werk, VIGS reeds besig was om soos 'n kanker op elke kontinent van die wêreld te vestig. Binne agt jaar sedert die eerste verskyning van VIGS word dit reeds as 'n pandemie beskryf. In plaas van oorbevolking staar groot gebiede van die wêreld, veral Afrika, ontvolking in die gesig. Die gevolge van hierdie eko-katastrofe kan op die oomblik nog nie bepaal word nie.

Dit is baie moeilik om enige gevestigde menslike denkpatroon te verander. Deur die jare heen is oorbevolking voorgehou as dié bedreiging vir die voortbestaan van die mensdom. Talle strategieë is uitgewerk om hierdie bedreiging die hoof te bied. Om nou skielik die teenoorgestelde standpunt aanvaar te kry, sal niks minder nie as ' $n$ mentale bollemakiesie verg.

Dit is baie duidelik dat daar ' $n$ aantal faktore binne die swart gemeenskap bestaan wat die verspreiding van VIGS bevorder. Geen geneesmiddel of vaksiene word in die afsienbare toekoms verwag nie. Die enigste wyse waarop die epidemie enigsins bekamp kan word, is deur voorligting en opvoeding. Tot tyd en wyl die erns van die VIGS-epidemie deur die swart gemeenskap aanvaar word, sal hierdie taak deur blankes uitgevoer moet word. Tyd is hier 'n baie belangrike faktor. Daar het reeds agt jaar verloop sedert die eerste gevalle in Suid-Afrika aangemeld is. Ons het ongeveer nog 
vier tot ses jaar om 'n demografiese ramp af te weer. In so 'n situasie sal daar geen wenners of verloorders wees nie; almal gaan op een of ander manier nadelig getref word. Om die hande in onskuld te was en te vra of ek dan my broeder se hoeder is, sal nie werk nie - dit het destyds ook nie gewerk nie. Daar is net een alternatief: elkeen moet hierdie gemeenskaplike vyand herken, erken en begin om iets daaraan te doen. NOU.

\section{BIBIJOGRAFIE}

BONNEUX, L. 1989. Risk factors for infeclion wilh human immunodeficiency virus among Europcan expat riates in Africa. British Medical Joumal, 279:581-584.

CLOUDSLEY-THOMPSON, J.L. 1977. What is an ccodisaster? Environmental Conservation, 4(1):66 68.

COSTAGLIOLA, D., MARY, J.Y., BROUARD, N., LAPORTE, A. \& VALLERON, A-J. 1989. Incubation time for AIDS from Frcnch Iransfusion-associalcd cases. Nature, 338:768-769.

DE COCK, K.M., ODEHOURI, K., MORAU, J., KOUADIO, J.C., PORTER, A., BARRERE, B. DIABY, L. \& HEYWARD, W.L. 1989. Rapid emergence of AIDS in Abidjan, Ivory Coast. The Lancet, 2(8660):408-411.

EDELSTON, K. 1988. Countdown to doomsday. Johannesburg : Media House Publications. 254 p

EUROPEAN STUDY GROUP. 1989. Risk factors for male to female transmission of HIV. British Medical Joumal, 298:411-415.

GIESECKE, J., SCALIA-TOMBA, G., BERGLUND, O., BERNTORP, E., SCHULMAN, S. \& STIGENDAL. I. 1988. Incidence of symptons and AIDS in 146 Swedish hacmophiliacs and blood transfusion recipients infecled with human immunodeficiency virus. British Medical Joumal, 279:99-102.

HOLMES, K. K. \& KREIS, J. 1988. Heterosexual Iransmission of human immunodeficiency virus: Overview of a neglected aspect of the AIDS epidemic. Joumal of Acquired Immune Deficiency Syndromes, 1:602-610.

JOHNSON, J.P., NAIR, P., HINES, S.E., SEIDEN, S.W., ALGER, L., REVIE, D.R., O'NEIL, K.M \& HEBEL, R. 1989. Natural history and scrologic diagnosis of infants born to human immunodefiency virus-infccled women. Americall Joumal of Diseases of Children, 134:1147. 1153.

KINGMAN, S. 1988. "Ten times more" AIDS cases in Africa. New Scientist, :20.

KONDE-LULE, J.K., BERKLEY, S.F. \& DOWNING, R. 1989. Knowledge, allitudes and praclices concerning AIDS in Ugandans. AIDS, 3(8):513-518.

LIFSON, A.R. 1988. Do alternate modes for Iransmission of human immunodeficiency virus exist? Joumal of the American Medical Association, 259(9):1353-1356.

LUI, K-J., DARROW, W.W. \& RUTHERFORD, G.W. 1988. A model-based estimate of the mean incubation period for AIDS in homoscxual men. Scicnce, 240:1333-1338

MANN, J.M. 1988. The international cpidemiology of AIDS. Scientific American, 259(4):60-69.

MOKHOBO, D. 1988. Scxual attitudes amongst black youths with special reference to AIDS. AIDS Procecdings: Sclected papers and lask group reports of the AIDS Congress. Strategies for Southern Africa '88. 29 April - 1 May 1988. Held in Johannesburg.

MOODIE, T.D. 1988. Migrancy and male sixuality on the South African gold mines. Joumal of Southem African Studies, 14(2):228-256.

MOSS, A.R. \& BACCHETTI, P. 1989. Nalural history of HIV infection. AIDS, 3(2):55-61.NAUDE, B 1990. Persoonlike mededeling aan outcur. Johannesburg. 
PIOT, P. \& LAGA, M. 1989. Gisaital ulcers, other sexually transmitted diseases, and the sexua transmission of HIV. British Medical Joumal, 298:623-624.

POLUNIN, N 1974. Thoughis on some conceivable ecodisasters. Enviromental Conservation, 1(3):177189 .

PRIOR, C.R.A \& EUCKLE, G.C. 1990. Flond donors with antibody to the human immunodeficiency virus - the Nalal experience. South African Medical Joumal, 7:623-625.

QUATTARA, S.A., MEITE, M. COT, M.C. \& de-TH\& G. 1989 . Compared prevalence of infections by HIV-1 and HIV-2 during a 2 year period in suhushan and rural areas of lvory Coast. Joumal of Acquined Immune Defiency Syndmmes, 2(1):94-99.

REEVES, G.K 1989. The overall distrihution of survival times for U.K. AIDS patients. Philosophical Transactions of the Royal Saciaty of timanon. B. 325:147-151.

ROOS, K.I. 1988. VIGS - Tol hier toe en verder. Geneeskunde, 31(8):16-19.

SANDBERG, S. \& AWER BUCH, T.E. 1989. Mathemalical formulation and studies of the risk parametcrs involved in HIV Iransmission. Hulletin of Mashematical Biology, 51(4):467-474

SCHNEIDER, B. 1989. Woman and AIDS. Futurí, 21(1):72-90

SUID AFRIKA (Republiek). 1983. Verslag vat die Welenskapskomitee van die Presidentsraad oor Demograficse Tendense in Suid-Afrika. Kaapstad : Staatsdrukker (PR/1983)

SUID AFRIKA (Republiek). 1990 Update: Al DS in South Africa - A Report of the South African Instilute for Medical Research:1-3. Frb 12.

VAN WYK, C.J. 1989. South Africa and the international community: The effects of sanctions and disinvesimunt on the South African econ omy. A speech delivered during a one-day simposium at the Vaal Triangle Technicon. Vandeclijlpark, 2 November 1989.

VIIJOEN A.T. 1988. AIDS and apartheid. The Lancet, 2(8674): 1280 . Nov. 25.

WORLD HEALTH ORGANIZATION. 19\%). Updale: AIDS cases reported to Surveillance, Forectsling and Impact Assessment Urit (SFI) Global I'rogram on AIDS 1 February 1990. Geneva, Switzerland. 
